\title{
Recovery of marine benthic habitats and fauna in a Swedish fjord following improved oxygen conditions
}

\author{
Rutger Rosenberg*, Stefan Agrenius, Birthe Hellman, Hans C. Nilsson, Karl Norling \\ Department of Marine Ecology, Göteborg University, Kristineberg Marine Research Station, 45034 Fiskebäckskil, Sweden
}

\begin{abstract}
The Gullmarsfjord on the Swedish west coast has a sill at $40 \mathrm{~m}$ and a maximum depth of $118 \mathrm{~m}$. The stagnant bottom water is usually renewed with oxygen-rich water each spring. In 1997 this did not occur, and the fauna was eliminated at depths below about $100 \mathrm{~m}$ and severely reduced between 80 and $100 \mathrm{~m}$ depth. In spring 1998, the whole fjord was re-oxygenated and the succession of the benthic fauna was studied at 5 stations over a $2 \mathrm{yr}$ period. Simultaneously, the benthic habitat quality (BHQ) was assessed by analysing sediment redox conditions and faunal burrow structures in sediment profile images. Succession of the benthic fauna is described as increases in number of species, abundance and biomass. Conspicuous colonisers below $100 \mathrm{~m}$ depth were the polychaete Capitella capitata and the heart urchins Echinocardium cordatum and E. flavescens. Return to preoxygen stressed conditions was slowest at the deepest stations. By using a multivariate technique (multi-dimensional scaling) we show that the benthic communities at all depths more or less returned to the same faunal composition as during pre-disturbed conditions. The pioneering and mature benthic faunal Successional Stages I and III were predictable but not the intermediate Stage II. The path of recovery of the benthic community succession did not retrace the path of degradation. The sedimentary habitats and redox conditions were similarly restored over the $2 \mathrm{yr}$ period as analysed by the BHQ index.
\end{abstract}

KEY WORDS: Sediment profile imaging $\cdot$ SPI $\cdot$ Hypoxia $\cdot$ Benthos $\cdot$ Faunal succession $\cdot$ Capitella

\section{INTRODUCTION}

The pioneering papers by Petersen (1913), Molander (1928) and Thorson (1957) documented that benthic macrofaunal species may be long-lived, and that the benthic community structure is tightly coupled to the sedimentary habitat. Later, successional models were developed showing that the structure of benthic communities changes in a predictable way in relation to environmental disturbance, e.g. organic enrichment (Pearson \& Rosenberg 1978), physical disturbance (Rhoads \& Germano 1982) and sediment toxicity (Swartz et al. 1985). Multivariate analysis has been useful in analysing disturbances of benthic communities (Warwick \& Clark 1993, Rumohr \& Karakassis 1999), but has also shown that different faunal groups may respond differently to enrichment and toxicity

*E-mail: r.rosenberg@kmf.gu.se
(Peterson et al. 1996). The models depicted the faunal distribution along a gradient of disturbance as a continuum, but for pedagogic reasons different successional stages were distinguished according to the degree of disturbance. Along an environmental gradient from severely disturbed to undisturbed conditions, the successional stages may be classified as Successional Stages (SS) 0 (grossly disturbed), I (pioneer/disturbed community), II (intermediate community), and III (undisturbed/'climax' community). Pearson \& Rosenberg $(1976,1978)$ showed in parallel studies from Scotland, where environmental disturbance increased, and Sweden, where the conditions improved after pollution abatement, that the benthic community structure was similar under similar degrees of disturbance even when the succession of these communities changed in different directions.

In the Gullmarsfjord on the Swedish Skagerrak coast (Fig. 1), the impact of declining oxygen concentrations 


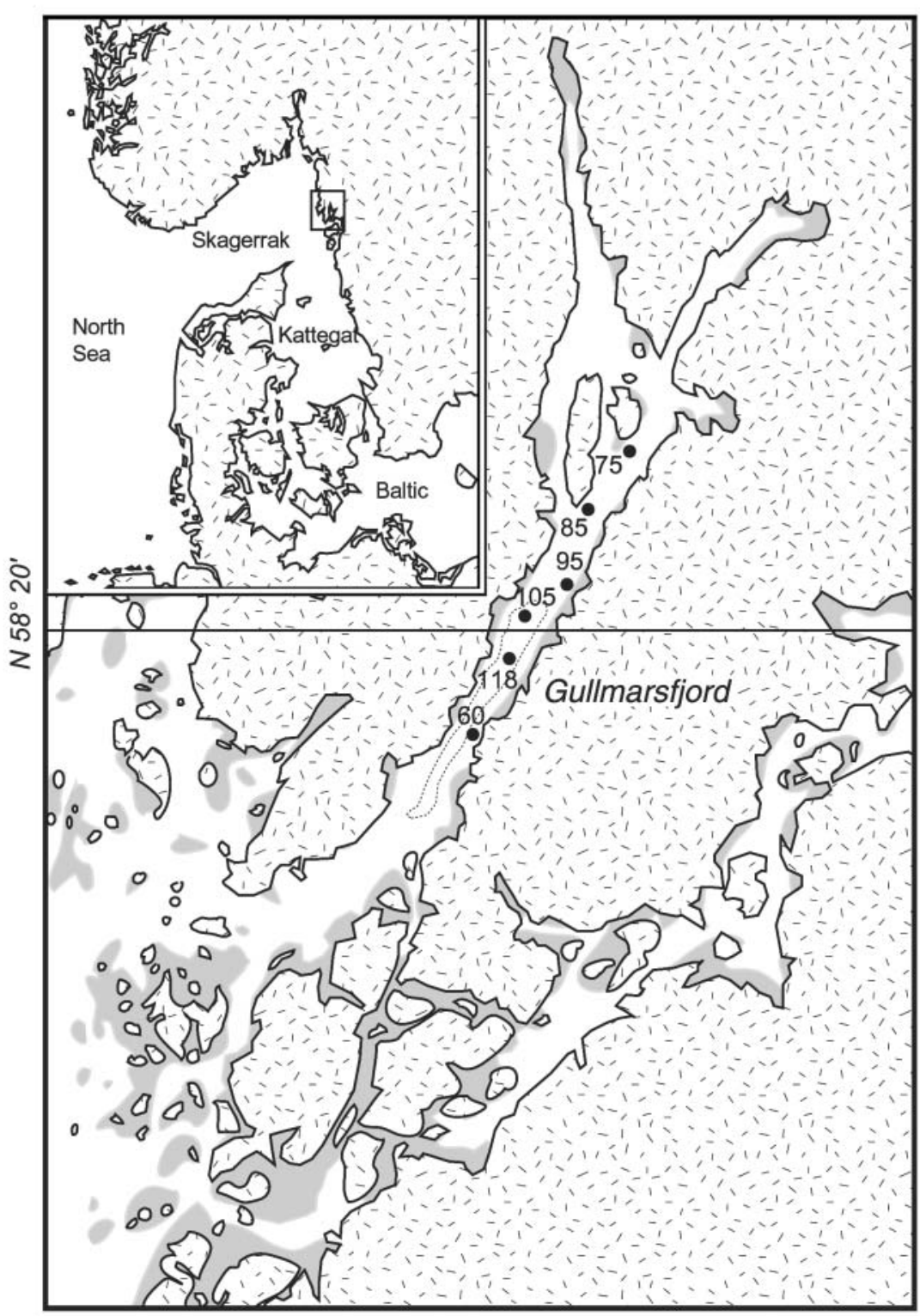

$E 11^{\circ} 20^{\prime}$

Fig. 1. Stations sampled in the Gullmarsfjord, west Sweden. Stations are numbered according to depth. Depth contour is $100 \mathrm{~m}$

fauna finally was eliminated. In Nilsson \& Rosenberg's study, the benthic habitat quality, e.g. redox conditions in the sediment, was assessed by analysing sediment profile images. At stations affected by hypoxia, the oxidised part of the sediment decreased, the reduced part increased, and the top sediment was finally disintegrated. At the studied depths, salinity is $\sim 34.5 \mathrm{psu}$, temperature between 4 and $8^{\circ} \mathrm{C}$ and sediment is predominantly mud.

In early 1998, the bottom water of the Gullmarsfjord was re-oxygenated, and for most of the period up to April 2000, the bottom oxygen saturations were $>20 \%$ (Fig. 2), i.e. above critical concentrations for at least most benthic infaunal species (Diaz \& Rosenberg 1995). Thus, this was an opportunity to study the succession of benthic communities from different initial successional stages. The questions are: Are the benthic successional models predictable, and are the paths of recovery and degradation similar? How long will it take to restore the sediment and to obtain a depth of redox potential discontinuity (RPD) similar to prehypoxic conditions? Models by Baden et al. (1990) and Gray (1992) have suggested that distribution of benthic fauna and sediment redox conditions change in relation to gradients of oxygen concentrations in a similar way as described in the Pearson-Rosenberg (1978) model.

In the present investigation, we used in situ sediment profile imaging (SPI) to digitally analyse biogenic structures and redox profiles of the sediments. This technique was developed by Rhoads \& Cande (1971) and has been

in the bottom water on benthic communities at different depths was investigated from June 1997 to April 1998 (Nilsson \& Rosenberg 2000). This decline in oxygen concentrations was an unusual event as the bottom water normally is exchanged once a year in winter or spring, but this water renewal did not occur during 1997. Instead the oxygen concentrations showed a temporal decline with depth. The benthic communities were more or less unaffected at 60 and $75 \mathrm{~m}$ (oxygen saturations remained $>15 \%$ ), significantly reduced at 85 and $95 \mathrm{~m}$ after oxygen saturation declined $<10 \%$, and severely affected at 105 and $118 \mathrm{~m}$, where the used to demonstrate changes in benthic habitats related to, e.g., organic enrichment (O'Connor et al. 1989) and physical disturbance (Rhoads \& Germano 1986). Nilsson \& Rosenberg (1997) used the SPI technique to develop a benthic habitat quality (BHQ) index, which in a recent study (Nilsson \& Rosenberg 2000) in the Gullmarsfjord correlated significantly with each of the variables species numbers, abundance and biomass. The BHQ index was used to assign the sedimentary quality and biogenic structures to the 4 different benthic successional stages (SS 0 to SS III) described above (Nilsson \& Rosenberg 2000). 


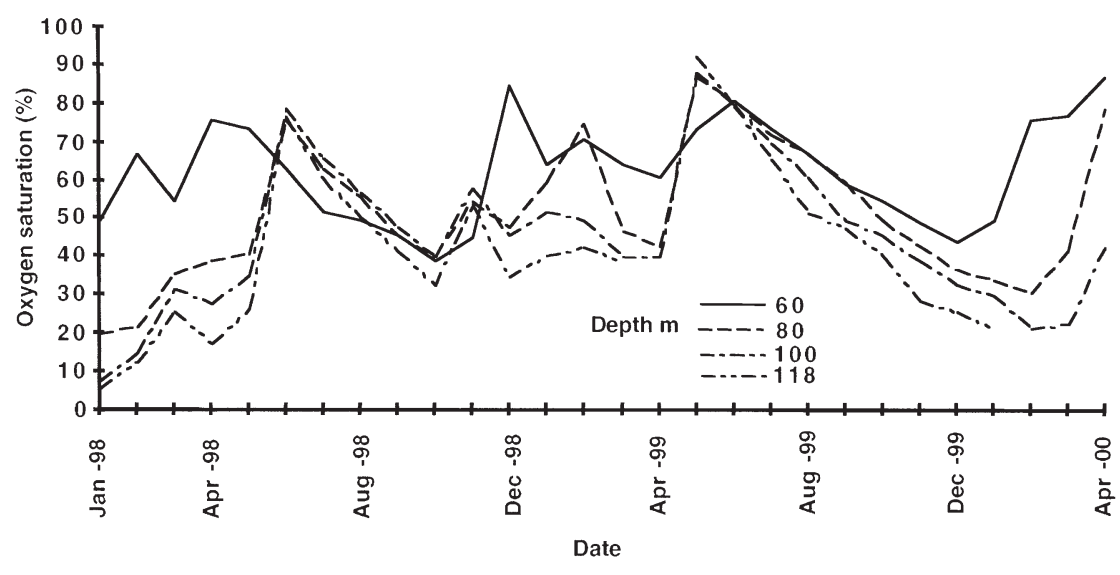

Fig. 2. Temporal changes in oxygen saturations (\%) from January 1998 to April 2000 at depths between 60 and 118 m measured by the Winkler method in the water on a depth transect at the deepest part of the Gullmarsfjord (data from the Gullmarsfjord Control Programme). The Water Quality Association of the Bohus Coast

\section{MATERIALS AND METHODS}

This study included 6 stations numbered after their depths: 60, 75, 85, 95, 105 and $118 \mathrm{~m}$. Sampling dates were April, June, August and October 1998; January, April, August and October 1999; and April 2000. Three SPIs were taken at each station, and 3 samples were taken with a $0.1 \mathrm{~m}^{2}$ Smith-McIntyre grab at the same stations and sampling times, except at $60 \mathrm{~m}$ where only SPIs were analysed. SPIs were taken in situ through a prism $(30 \times 22$ cm; Rosenberg \& Diaz 1993) penetrating about $12 \mathrm{~cm}$ into the sediment. Cameras used were a Nikon 801 (with ISO 100 color-positive film, E6-developed) up to April 1999 and thereafter a digital CCD camera (Canon Power Shot Pro 70). Contrasts in the colours were digitally enhanced in Adobe Photoshop 5.5, which allowed accurate assessment of the depth of the apparent redox potential discontinuity (aRPD) measured as the shift between oxidised yellowish top sediment and reduced black sediment below (Rosenberg et al. 2001). The BHQ index was calculated from each image. This index parameterises sediment structures, sub-surface structures, and the depth of the aRPD (Nilsson \& Rosenberg 1997). The BHQ index varies between 0 and 15 and is related to the benthic fauna successional stages of the Pearson-Rosenberg model (Nilsson \& Rosenberg 2000), where $\mathrm{BHQ}<2$ relates to $\mathrm{SS} 0, \mathrm{BHQ}=2-4$ to SS I, BHQ $=5-10$ to SS II, and BHQ $>10$ to SS III. The SmithMcIntyre grab took samples down to $\sim 17 \mathrm{~cm}$ depth in the sediment at all stations; the sediment was sieved on $1 \mathrm{~mm}$ mesh and preserved in $4 \%$ buffered formalin. Numerical similarity between macrofaunal samples was analysed by multi-dimensional scaling (MDS) based on Bray-Curtis similarity index after $\sqrt{ } \sqrt{ }$ transformation (Clark \& Warwick 1994). Correlations between BHQ index and number of species, abundance and biomass were analysed by simple linear correlation [log $(x+10)]$. Biomass is formalin wet weight. Carbon $(\mathrm{C})$ and nitrogen $(\mathrm{N})$ of the top of the sediment were analysed at the same time in 2 replicate deepfrozen samples from each station in April 1999 and 2000 in a Carlo Elba elemental analyser. Loss of ignition was analysed on 4 replicates of the top $1 \mathrm{~cm}$ of the sediments from April 2000 after drying at $80^{\circ} \mathrm{C}$ to constant weight and subsequent burning at $500^{\circ} \mathrm{C}$ for $5 \mathrm{~h}$. Statistical analysis in differences as percent $\mathrm{C}$ and $\mathrm{N}$ between sampling times was made by ANOVA.

\section{RESULTS}

\section{Sediment and sediment profile imaging}

Percent fines $(<16 \mu \mathrm{m})$ of the sediment was $\geq 94 \%$ at all stations except Stn 95, where the sediment had coarser particles (Table 1). In April 1999, means of C varied between 3.7 and $4.2 \%$ with higher values at the deep stations (Table 1). In April 2000, the mean content of $\mathrm{C}$ had declined significantly (ANOVA, $\mathrm{p}<0.05$ ) at all stations to between 3.2 and $4.0 \%$. Similarly, a significant (ANOVA, $\mathrm{p}<0.05$ ) decline was recorded for mean $\mathrm{N}$, ranging between 0.32 and $0.35 \%$ in 1999 to between 0.26 and $0.33 \% 1 \mathrm{yr}$ later. The mean loss of ignition was $>10 \%$ dry weight at all stations, except at Stn 95 where it was $7.8 \%$.

Table 1. Depth and position of the benthic stations in the Gullmarsfjord, west Sweden. Mean percent C, N, loss of ignition (LI), and percent fine sediment $\left(\mathrm{FS}_{;}<16 \mu \mathrm{m}\right)$ in the top $\mathrm{cm}$ of the sediment in April 1999 and 2000

\begin{tabular}{|c|c|c|c|c|c|c|c|c|}
\hline \multirow{2}{*}{$\begin{array}{l}\text { Stn } \\
\text { (depth, m) }\end{array}$} & \multicolumn{2}{|c|}{ Position } & \multicolumn{2}{|c|}{$\mathrm{C}$} & \multicolumn{2}{|c|}{$\mathrm{N}$} & \multirow{2}{*}{$\begin{array}{c}\text { LI } \\
2000\end{array}$} & \multirow{2}{*}{$\begin{array}{c}\text { FS } \\
2000\end{array}$} \\
\hline & $\mathrm{N}$ & $E$ & 1999 & 2000 & 1999 & 2000 & & \\
\hline 75 & $58^{\circ} 22.7^{\prime}$ & $11^{\circ} 36.6^{\prime}$ & 3.7 & 3.6 & 0.34 & 0.31 & 10.5 & 96 \\
\hline 85 & $58^{\circ} 21.7^{\prime}$ & $11^{\circ} 35.2^{\prime}$ & 3.8 & 3.6 & 0.34 & 0.30 & 10.8 & 98 \\
\hline 95 & $58^{\circ} 20.4^{\prime}$ & $11^{\circ} 34.7^{\prime}$ & 3.7 & 3.2 & 0.32 & 0.26 & 7.8 & 76 \\
\hline 105 & $58^{\circ} 15.0^{\prime}$ & $11^{\circ} 26.8^{\prime}$ & 4.2 & 4.0 & 0.35 & 0.33 & 11.2 & 95 \\
\hline 118 & $58^{\circ} 19.4^{\prime}$ & $11^{\circ} 32.7^{\prime}$ & 4.2 & 3.9 & 0.35 & 0.31 & 12.4 & 94 \\
\hline
\end{tabular}


$75 \mathrm{~m}$
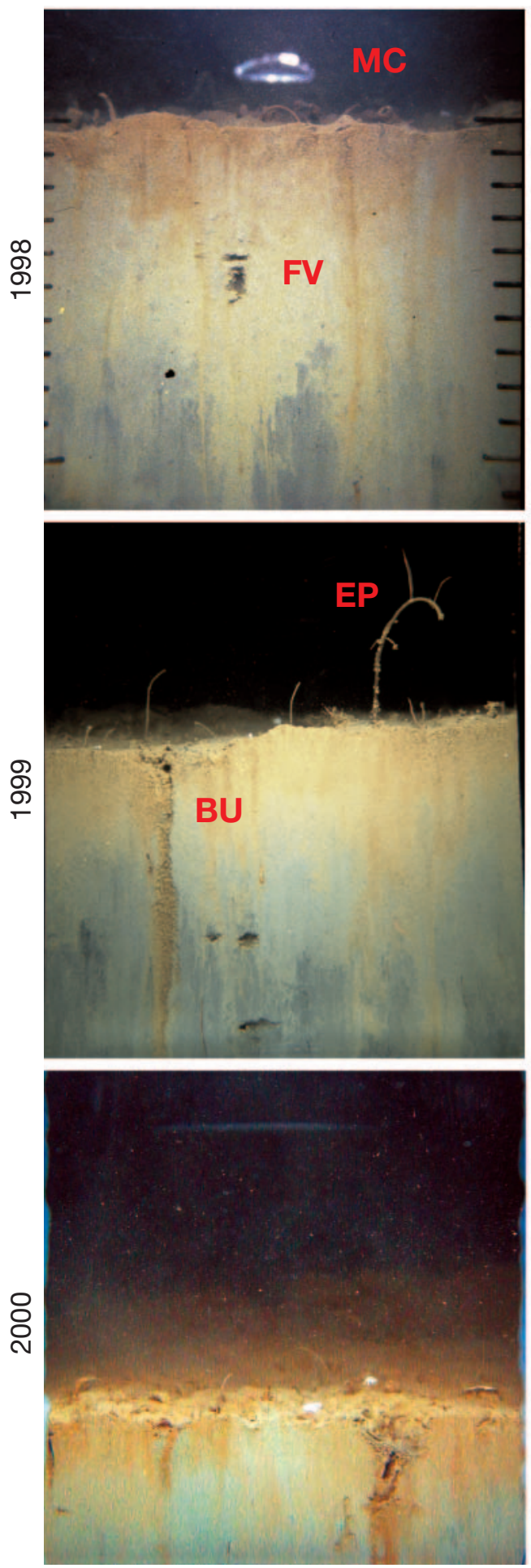

$95 \mathrm{~m}$
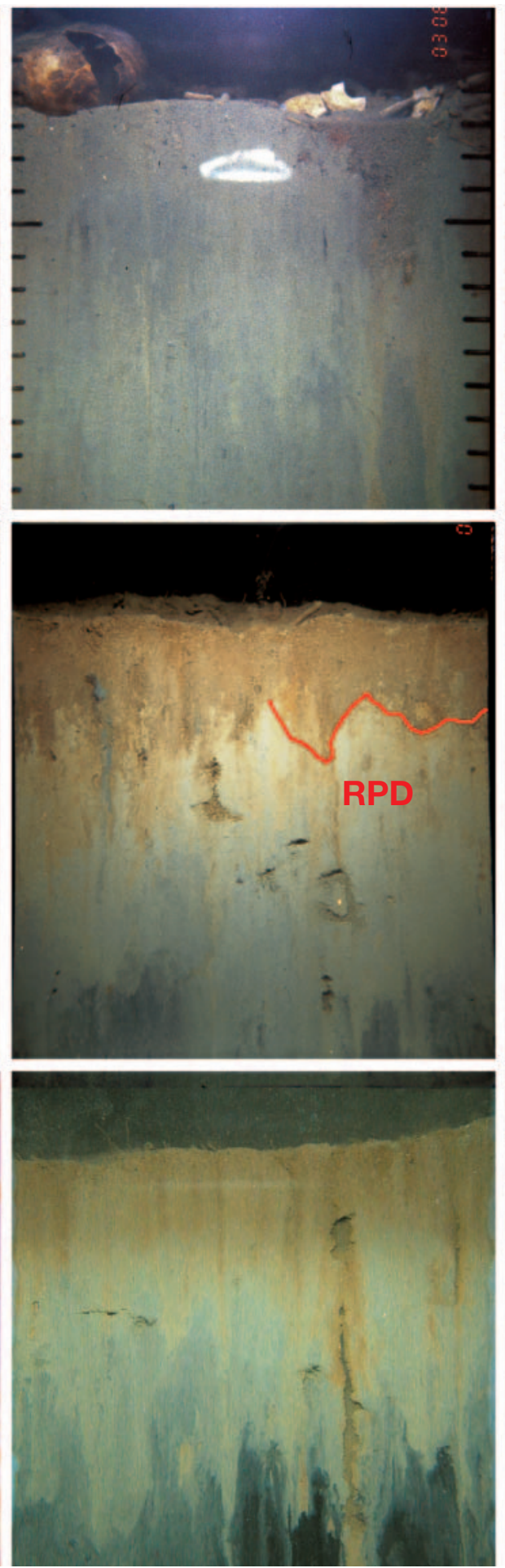

$105 \mathrm{~m}$
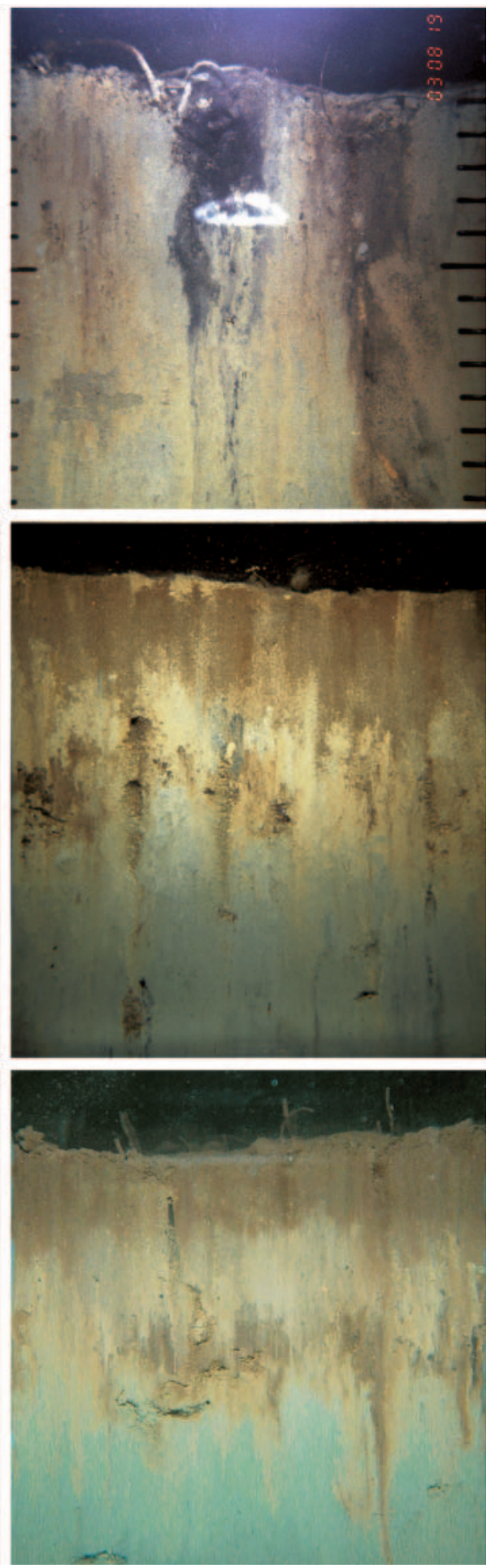

Fig. 3. Sediment profile images from April 1998, 1999 and 2000 at 75, 95 and $105 \mathrm{~m}$ depth in the Gullmarsfjord. Scales on the sides of images from 1998 are in centimetre intervals. BU: burrow; FV: feeding void; RPD: redox potential discontinuity; EP, MC: tubes that appear to be Euchone papillosa and Melinna cristata tubes, respectively. Halo is an artifact (reflection of flash); colours in images are computer enhanced 
SPIs from April 1998, 1999 and 2000 are shown for Stns 75, 95 and 105 in Fig. 3. In 1998, the sediment at Stn 75 appeared undisturbed. Tubes were seen on the sediment surface, the largest probably being Melinna cristata tubes. The upper 2 to $3 \mathrm{~cm}$ of the sediment was oxidised, with several burrows extending down below this depth and 1 void. At Stn 95, the SPI showed fragments of sea urchin tests and polychaete tubes. The sediment appeared reduced to the surface on the left side, and a pit on the right indicated recent activity. The sediment at Stn 105 appeared reduced, with black fragments of tubes, reduced old burrow structures, and 1 anoxic, black void.

In 1999, several tubes that appeared to be those of Euchone papillosa extended several centimetres up into the water at Stn 75 (Fig. 3). The branches of 1 tube in the front of the image are suggested to be constructed by the crustacean Dyopedos monacanthus (Mattson \& Cedhagen 1989). Three voids, and 1 long burrow extending $>9 \mathrm{~cm}$ into the sediment were also present. At Stn 95, the upper $\sim 1 \mathrm{~cm}$ was reworked and the aRPD was at 2 to $3 \mathrm{~cm}$ depth. One tube and several burrows and voids were present in the image. At Stn 105, the upper 2 to $3 \mathrm{~cm}$ was oxidised, with several burrows and voids deeper down in the sediment.

In 2000, the penetration of the prism was poor at Stn 75, resulting from mechanical failure. The thin tubes protruding above the surface (Fig. 3) appeared to be Euchone papillosa and the larger Melinna cristata. Burrows penetrated down below the lower part of the image. At Stn 95, the upper $\sim 3 \mathrm{~cm}$ of the sediment was oxidised in the image, and some small tubes were present on the surface. The large burrow on the right penetrated $>12 \mathrm{~cm}$ down in the sediment. Some voids were also present. At Stn 105, the upper 2 to $3 \mathrm{~cm}$ of the sediment was oxidised, and some tubes protruded into the water. One large burrow $>15 \mathrm{~cm}$ long and some smaller ones were noted in the sediment.

The mean depth of the aRPD measured in the SPIs over the sampling period varied around $5 \mathrm{~cm}$ on Stn 60 and between 3 and $4 \mathrm{~cm}$ at Stn 75 (Fig. 4). At the deeper stations, aRPD showed a general increase over the whole period from values $\sim 1$, and reached values similar to that at Stn 75 in April 1999.

The mean values of the BHQ index were $\geq 10$ at Stns 60 and 75 over the whole study. At the deeper stations, BHQ indices increased from means of $<5$ in April 1998 to $>10$ for Stns 85 and 95 two years later. At that time, in April 2000, the mean BHQ indices at Stns 105 and 118 were 9.7 and 8.0, respectively.

\section{Species, abundance and biomass}

The 5 dominant species recorded at each station for samplings in April 1998, 1999 and 2000 are listed in Table 2. Dominant species at Stn 75 during the whole

Table 2. Mean abundance (ind. $\mathrm{m}^{-2}$ ) of 5 dominant species, and total abundance and number of species at each station in the Gullmarsfjord in April 1998, 1999 and 2000

\begin{tabular}{|c|c|c|c|c|c|c|c|c|c|c|c|c|c|c|c|}
\hline Taxon & 1998 & $\begin{array}{l}75 \mathrm{~m} \\
1999\end{array}$ & 2000 & 1998 & $\begin{array}{l}85 \mathrm{~m} \\
1999\end{array}$ & 2000 & 1998 & $\begin{array}{l}95 \mathrm{~m} \\
1999\end{array}$ & 2000 & 1998 & $\begin{array}{r}105 \mathrm{~m} \\
1999\end{array}$ & 2000 & 1998 & $\begin{array}{c}118 \mathrm{~m} \\
1999\end{array}$ & 2000 \\
\hline Abra nitida & 477 & 210 & 293 & 0 & 0 & 7 & 0 & 97 & 53 & 0 & 7 & 30 & 33 & 10 & 147 \\
\hline Amphicteis gunneri & 50 & 50 & 53 & 0 & 60 & 123 & 0 & 70 & 143 & 0 & 0 & 17 & 0 & 0 & 3 \\
\hline Amphiura filiformis & 107 & 187 & 240 & 0 & 0 & 0 & 0 & 0 & 0 & 0 & 0 & 0 & 3 & 3 & 3 \\
\hline Anobothrus gracilis & 77 & 80 & 113 & 13 & 33 & 107 & 3 & 43 & 37 & 0 & 0 & 23 & 0 & 0 & 13 \\
\hline Capitella capitata & 0 & 0 & 0 & 43 & 0 & 0 & 407 & 0 & 0 & 960 & 0 & 0 & 1300 & 0 & 0 \\
\hline Chaetozone setosa & 13 & 7 & 73 & 17 & 87 & 70 & 0 & 207 & 107 & 0 & 0 & 0 & 0 & 0 & 13 \\
\hline Chlamys septemradiatus & 0 & 13 & 13 & 0 & 3 & 23 & 0 & 13 & 0 & 0 & 0 & 57 & 0 & 0 & 0 \\
\hline Echinocardium cordatum & 13 & 13 & 20 & 0 & 30 & 0 & 0 & 0 & 0 & 0 & 200 & 13 & 0 & 220 & 3 \\
\hline Echinocardium flavescens & 27 & 20 & 17 & 0 & 0 & 3 & 0 & 73 & 13 & 0 & 390 & 30 & 0 & 173 & 13 \\
\hline Euchone papillosa & 10 & 23 & 17 & 0 & 177 & 63 & 0 & 33 & 0 & 0 & 0 & 17 & 0 & 3 & 0 \\
\hline Heteromastus filiformis & 790 & 330 & 190 & 13 & 23 & 10 & 3 & 173 & 100 & 3 & 0 & 0 & 0 & 17 & 13 \\
\hline Lipobranchus jeffreysi & 0 & 0 & 13 & 0 & 160 & 147 & 0 & 13 & 7 & 0 & 3 & 0 & 0 & 3 & 0 \\
\hline Maldane sarsi & 323 & 217 & 110 & 3 & 13 & 0 & 0 & 0 & 0 & 0 & 0 & 0 & 0 & 0 & 0 \\
\hline Melinna cristata & 230 & 113 & 123 & 207 & 167 & 150 & 63 & 80 & 113 & 0 & 0 & 23 & 3 & 0 & 10 \\
\hline Myriochele oculata & 67 & 167 & 117 & 0 & 0 & 3 & 0 & 133 & 43 & 0 & 0 & 17 & 0 & 0 & 0 \\
\hline Mysella bidentata & 47 & 190 & 193 & 0 & 0 & 3 & 0 & 7 & 3 & 0 & 0 & 0 & 0 & 0 & 3 \\
\hline Nemertini spp. & 117 & 10 & 43 & 180 & 13 & 13 & 320 & 47 & 7 & 0 & 7 & 0 & 0 & 0 & 7 \\
\hline Nereimyra sp. & 33 & 7 & 3 & 233 & 220 & 87 & 7 & 10 & 7 & 0 & 63 & 153 & 0 & 57 & 180 \\
\hline Nuculoma tenuis & 317 & 3 & 3 & 0 & 23 & 17 & 0 & 7 & 7 & 0 & 0 & 0 & 0 & 0 & 7 \\
\hline Ophelina acuminata & 0 & 0 & 27 & 0 & 90 & 153 & 0 & 30 & 97 & 0 & 0 & 183 & 0 & 0 & 83 \\
\hline Scalibregma inflatum & 3 & 7 & 160 & 0 & 320 & 60 & 0 & 117 & 87 & 0 & 17 & 10 & 0 & 10 & 27 \\
\hline Spiophanes kroyeri & 413 & 237 & 177 & 0 & 0 & 3 & 0 & 30 & 53 & 0 & 0 & 10 & 0 & 3 & 27 \\
\hline Thyasira equalis & 97 & 43 & 143 & 143 & 153 & 70 & 0 & 7 & 60 & 0 & 10 & 113 & 3 & 10 & 143 \\
\hline Thyasira sarsi & 67 & 63 & 53 & 120 & 143 & 53 & 87 & 613 & 180 & 0 & 70 & 377 & 0 & 117 & 663 \\
\hline Total abundance & 3623 & 2230 & 2680 & 1007 & 1780 & 1390 & 910 & 1947 & 1210 & 963 & 833 & 1270 & 1343 & 690 & 1573 \\
\hline Total no. of species $\left(0.3 \mathrm{~m}^{-2}\right)$ & 51 & 48 & 52 & 14 & 27 & 35 & 13 & 42 & 26 & 2 & 19 & 33 & 5 & 24 & 39 \\
\hline
\end{tabular}


period, and found in numbers $>100$ ind. $\mathrm{m}^{-2}$, were the bivalve Abra nitida, the polychaetes Maldane sarsi, Melinna cristata, Heteromastus filiformis and Spiophanes kröyeri, and the brittle star Amphiura filiformis. At Stns 85 and 95, M. cristata and the bivalve Thyasira sarsi were abundant over the whole period. The following polychaetes had increased in numbers by the last 2 sampling periods: Amphicteis gunneri, Chaetozone setosa, Ophelina acuminata and Scalibregma inflatum. At the deep stations (Stns 105 and 118), which had no macrofauna in February 1998, Capitella capitata was the initial coloniser in April 1998. In the following 2 yr conspicuous species were the heart urchins Echinocardium cordatum and E. flavescens, the bivalves T. sarsi and T. equalis, and the polychaete Nereimyra sp. On the last sampling date, the polychaetes O. acuminata, Anobothrus gracilis and $M$. cristata were found.

The greatest number of species over the sampling period was generally found at Stn 75 (Fig. 4). At the other stations there was a general and gradual increase in numbers, except at Stn 95, where the numbers reached 29 species per $0.3 \mathrm{~m}^{2}$ in August 1999, but declined to 20 species in April 2000. The abundance was generally highest at Stn 75 , but showed great variation over time. Abundance at the other stations was also variable over time, with peaks in August 1999 at Stns 85 and 95. In April 2000, the abundance at all stations except Stn 75 was similar, with means between 121 and 157 ind. per $0.1 \mathrm{~m}^{2}$. On most sampling
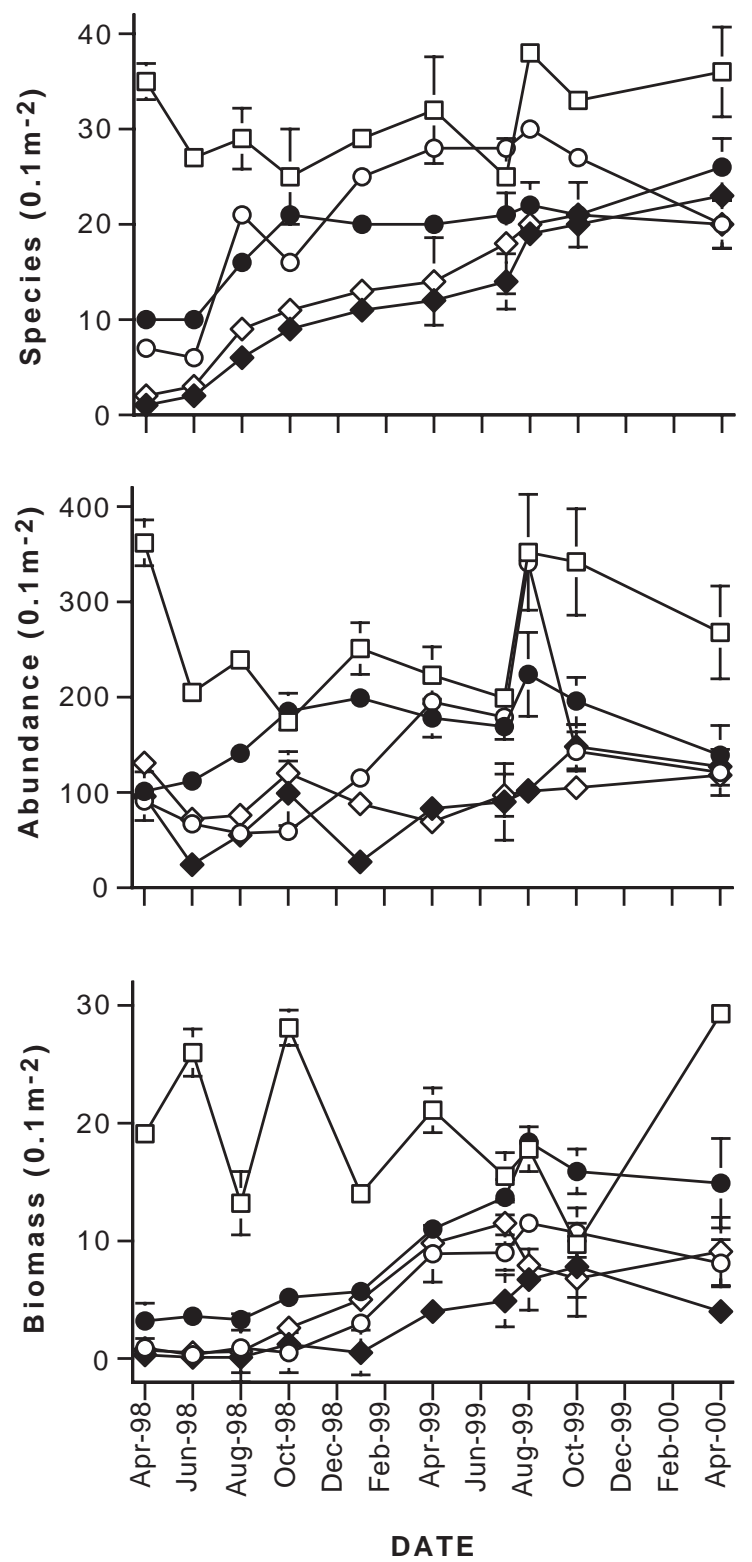
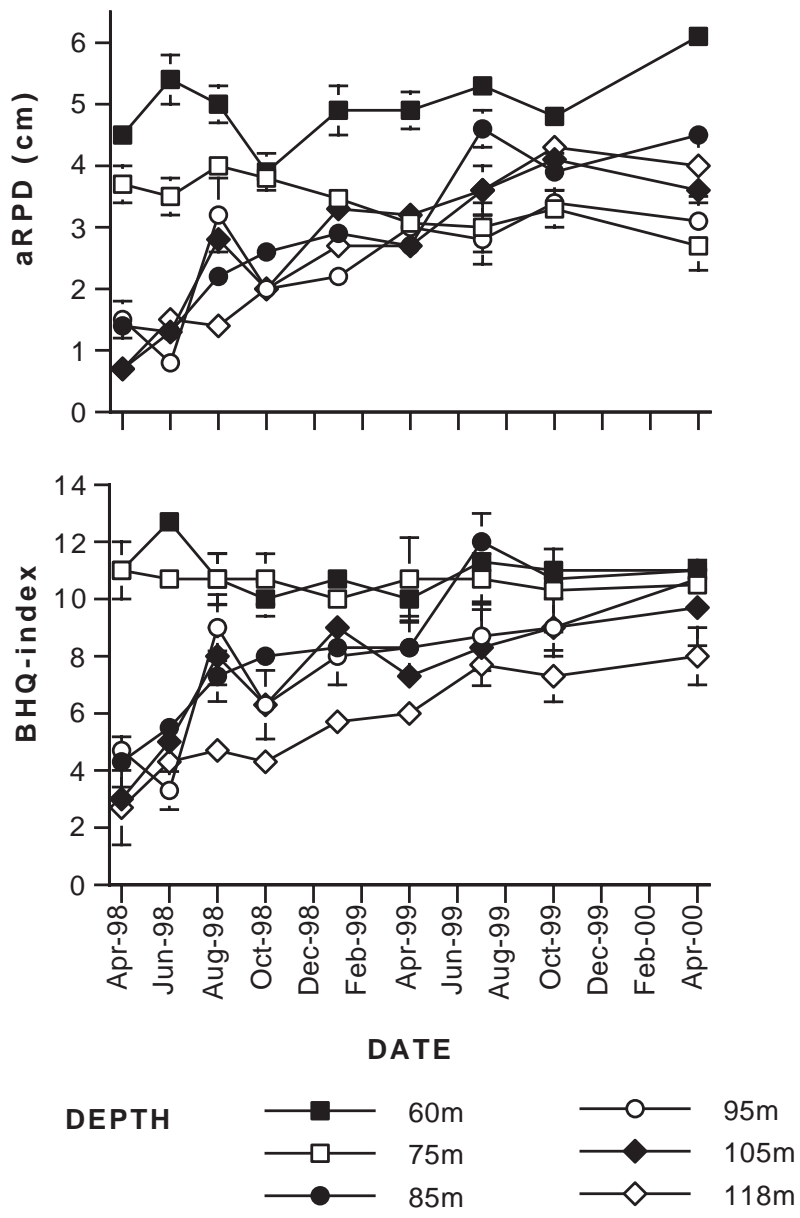

Fig. 4. Succession in number of species, abundance and biomass (means $\pm \mathrm{SE}, \mathrm{n}=3$ ) from April 1998 through April 2000 between 75 and $118 \mathrm{~m}$ depth in the Gullmarsfjord. Means of apparent redox potential discontinuity (aRPD) and benthic habitat quality $(\mathrm{BHQ})$ indices (means $\pm \mathrm{SE}, \mathrm{n}=3$ ) for the same period and depths (including $60 \mathrm{~m}$ ) and analysed from sediment profile images are shown in the right-hand panels 
occasions, biomass was highest at Stn 75, but varied between sampling dates. At the other stations, the recovery in biomass was minor during 1998, but increased after this, particularly at Stn 85. Temporal changes in the logarithm of number of species, abundance and biomass were significantly $(p=0.001)$ correlated with the $\mathrm{BHQ}$ indices (correlation coefficients of $\mathrm{r}=0.81,0.56$ and 0.71 , respectively).

\section{Benthic community recovery pattern}

Benthic community succession following re-oxygenation of the bottom water in the Gullmarsfjord is illustrated using a multivariate statistical analysis (Fig. 5). No. 1 represents the 3 replicate samples taken in April 1998 when colonisation was first observed, No. 2 the second sampling date, etc., according to the dates given in Fig. 4. At the reference station (Stn 75), no apparent directional change was observed, but there was a tendency for the replicates to be close to each other. At Stn 85, the fauna for the first 2 dates was similar; the faunal composi- tion changed at Sampling Time 3, was similar over Samplings 4 through 9, and then changed somewhat more at Sampling Time 10. At Stn 95, successive changes were apparent between the first 5 sampling dates; subsequently, the faunal composition was comparatively more similar. Stns 105 and 118 showed a progressive change to the end of the sampling. The faunal composition was rather similar at the 2 first samplings, with a subsequent larger change at the third and fourth samplings, with a gradual change during the following samplings up to the final sampling date. (Note that the scales are not comparable between the station plots in Fig. 5.) For comparison of faunal succession between stations, we combined the average faunal composition on each sampling date into 1 graph (bottom, right-hand panel in Fig. 5), which indicates that the faunal composition at Stn 75 was similar over the whole $2 \mathrm{yr}$ period, and that the fauna changed to a minor degree at Stn 85, and to a higher degree at Stn 95. The comparatively greatest change occurred at Stns 105 and 118, and the faunal composition during recovery at these stations was similar.
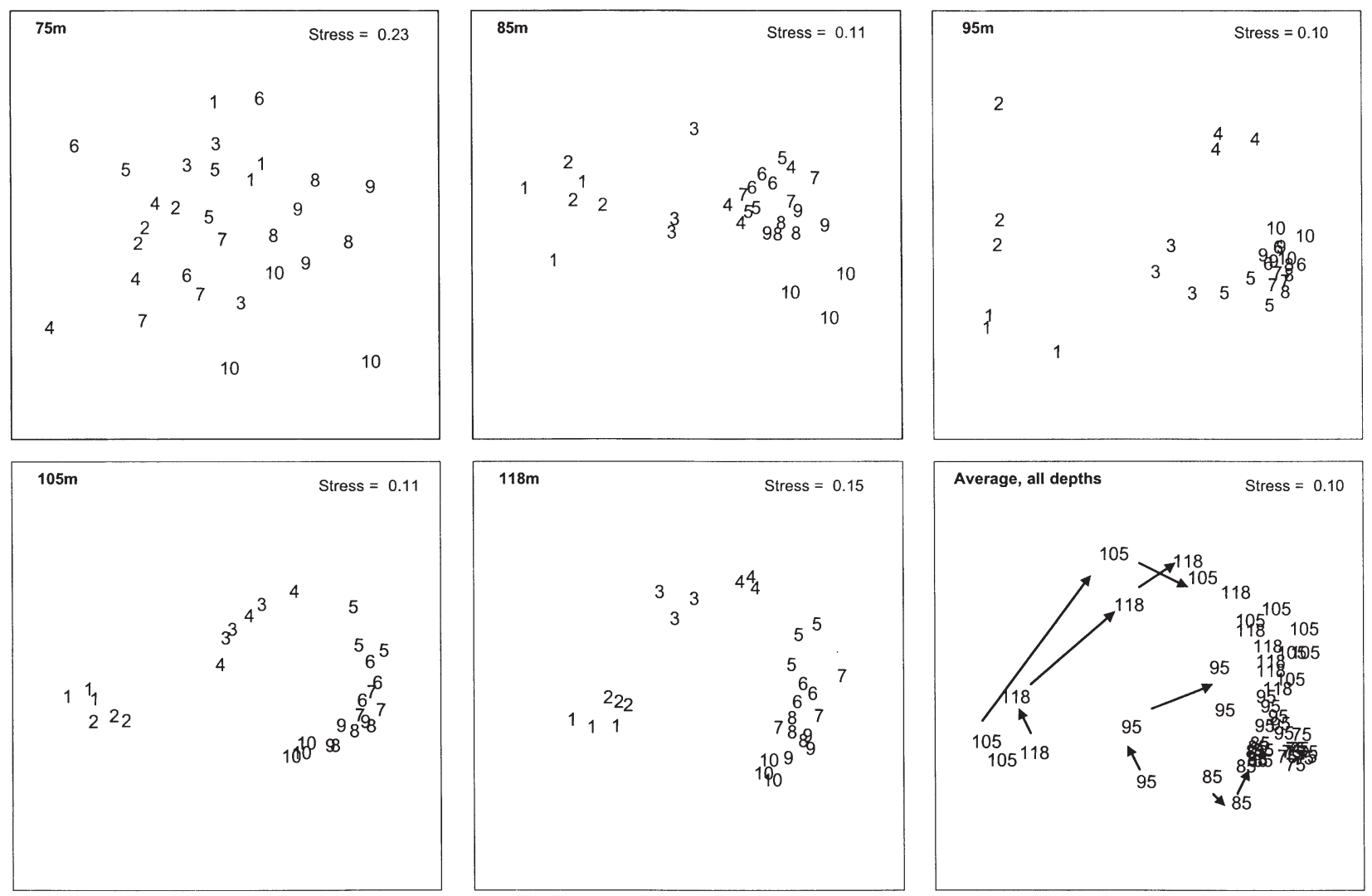

Fig. 5. Multi-dimensional scaling (MDS) showing the changes in benthic community structure from April 1998 through April 2000 $(\mathrm{n}=10)$ at the depths $75,85,95,105$ and $118 \mathrm{~m}$. 1 is the first sampling date, 2 the second sampling date, etc., each with 3 replicates. In the bottom, right-hand panel, means of the fauna for all depths are combined and arrows indicate the temporal recovery. 


\section{DISCUSSION}

\section{Comparison with other studies}

Molander $(1928,1963)$ has contributed most to the knowledge of distribution of different benthic communities in the Gullmarsfjord. His investigations during the years 1923 through 1926 formed the basis for his classification of 10 separate associations and several more sub-communities (facies). In the deeper part (72 to $118 \mathrm{~m}$ ) of the fjord, i.e. approximately the same depth interval as sampled in the present study, he characterised the community as a Melinna cristataNucula tenuis assemblage. Molander (1928) found 42 species at 3 stations ( 3 replicates of $0.1 \mathrm{~m}^{2}$ each); this seems to be lower than that in the present study, but a comparison is difficult as different grabs and sorting techniques were used. For the 3 stations he listed, average densities (given as ind $\mathrm{m}^{-2}$ ) of the dominant species were as follows: M. cristata 72, Nuculoma tenuis 193, Abra nitida 118, and Thyasira spp. 110. The same taxa were among the dominant species in the present study also (Table 2), except for $N$. tenuis which was present as shells only.

The response of benthic fauna to hypoxia was studied at the deepest station at $118 \mathrm{~m}$ in the Gullmarsfjord by Josefson \& Widbom (1988) in 1977 to 1981. During the winter 1979/1980, oxygen concentration declined to a minimum of $0.21 \mathrm{ml} \mathrm{l}^{-1}$, and the macrobenthos was eliminated. Later in 1980, Capitella capitata and Heteromastus filiformis colonised the area, but the recovery was halted by a new decline in oxygen concentration later that year. Gustafsson \& Nordberg (2001) found major changes in foraminiferan species composition between 1927 and 1994 towards species more tolerant to hypoxia. In many parts of the world, e.g. in Japan (Tsutsumi 1987), species of the genera Capitella are rapid colonisers following cessation of hypoxia and are frequently associated with organic enrichment (e.g. Pearson \& Rosenberg 1978, Weston 1990).

In the innermost part of the Gullmarsfjord, the Saltkällefjord, outlets from a sulphite pulp mill enriched the bottoms up to 1966 to such an extent that the fauna was eliminated in the inner area of that fjord, due to oxygen deficiency in the bottom water and hydrogen sulphide in the sediment (Bagge 1969, Leppäkoski 1975). Leppäkoski (1975) described how the benthic faunal communities changed in time and space, or as he called it, moved as 'migrating communities' from the inner part to the outer part of the fjord along with increasing pollution. Following the discontinuation of the pulp mill in 1966, the first colonisers, Capitella capitata and Malacoceros (Scolelepis) fuliginosus, did not appear until 1969 on the most enriched bottoms (Rosenberg 1972). Thus it took about 3 yr for the top sediment to recover to an extent that made it suitable for macrofaunal life. The benthic community succession documented here contributed to the development of the Pearson-Rosenberg model, and once initiated the recolonisation of different species and increases in their densities were rapid. After 5 to $8 \mathrm{yr}$, depending on the area of the fjord, the faunal structure was considered as having returned to pre-pollution levels and resembled that described $40 \mathrm{yr}$ earlier (Rosenberg 1976). The longer time for recovery compared to the present study was due to the severe organic enrichment of the sediment. Recovery to a community structure that is normal to a particular habitat depends on several environmental factors, e.g. severity of the hypoxia (Llansó 1992), salinity, temperature, current regimes, latitude, etc. Recovery is generally more rapid in shallow waters than in deeper waters (Diaz \& Rosenberg 1995). An exception to this was, however, the benthic faunal recovery rate in one of the largest lagoons in the western Mediterranean, the Orbetello lagoon in Italy. This lagoon was affected by anoxic crises in 1992 and 1993, with resultant drastic reductions in benthic fauna and fish mortality. In 1999, 6 yr after anoxia, a clear recovery was observed, but opportunistic species still dominated (Lardicci et al. 2001). The reason for this slow recovery is suggested as being due to the lagoon being enclosed, with poor water interchange with the sea.

\section{Recovery of the benthic fauna}

The significant reduction in mean $\mathrm{C}$ and $\mathrm{N}$ of the top sediment between April 1999 and April 2000 could have been a result of increased mineralisation related to increased maturity of the benthic communities and associated increased bioturbation rates. The amount of phytodetritus settling on the bottom was, however, probably much greater in 1999 compared to 2000, as the accumulated primary production in the Gullmarsfjord between early January and mid-April in each of these years was calculated as $74.0 \mathrm{~g} \mathrm{C} \mathrm{m}^{-2}(\mathrm{n}=7)$ in 1999 and 18.6 ( $\mathrm{n}=10$ ) $\mathrm{g} \mathrm{C} \mathrm{m}^{-2}$ in 2000 (O. Lindahl pers. comm.). Thus, the differences in primary production were most probably coupled to differences in organic matter content of the sediment. The greatest difference in sediment properties between stations was at Stn 95, where organic matter was slightly lower and sediment slightly coarser than at the other stations, probably because this station was situated on the slope of the deep basin.

All investigated stations had similar salinity and temperature and fairly similar sediment-grain sizes; therefore, the ecological factors that would have had the greatest impact on the succession in the benthic communities are the difference and the temporal change in 
oxygen concentrations at different depths in 1997 to early 1998. During the time of the present and a previous study (Nilsson \& Rosenberg 2000), covering the 35 mo period from June 1997 to April 2000, oxygen was recorded every month and the fauna and SPI were sampled a total of 15 times, i.e. on average almost every second month. This time series, and the dynamic faunal changes occurring over that period, allowed, probably for the first time, a test of the predictability of the Pearson-Rosenberg successional model in relation to increased hypoxia followed by improved oxygen conditions, i.e. will benthic communities that are disturbed to different degrees by hypoxia return to predisturbed conditions?

We used a multivariate analysis to show the successional changes during this 35 mo period (Fig. 6). Data from June 1997 to April 1998 are from Nilsson \& Rosenberg (2000). Each number represents the mean from 1 sampling date. In June 1997, the benthic community structures at Stns 75, 85 and 95 grouped into an octagonal in Fig. 6, here named the 'climax' community, equal to SS III. The faunal composition at Stn 75 remained unchanged throughout this study, demonstrating its usefulness as a reference station. In the pre-
105

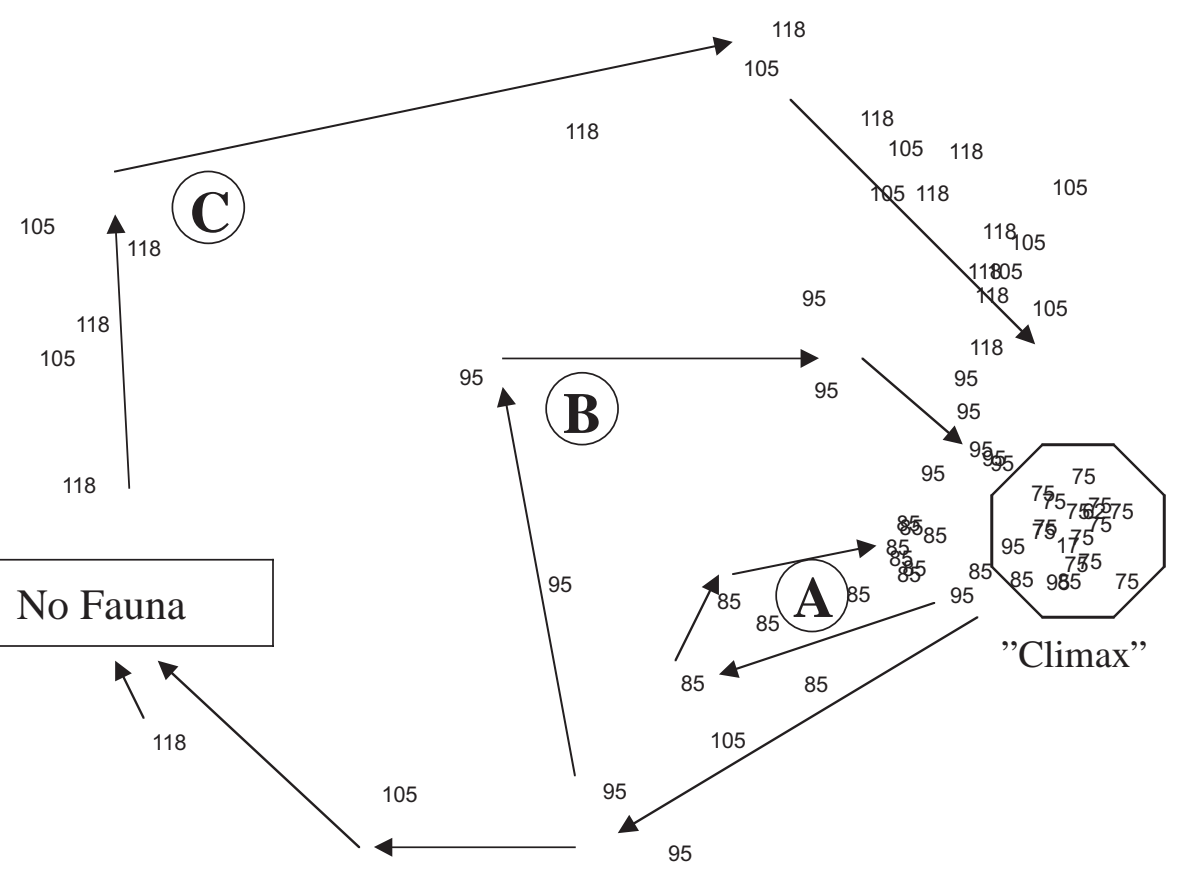

105 vious study (Nilsson \& Rosenberg 2000), the $60 \mathrm{~m}$ station was also used as a reference for faunal changes, and both stations had a similar faunal composition. The means of the BHQ indices were $>10$ for the whole period. The faunal composition at Stn 85 (as illustrated in the MDS-plot: Fig. 6, Loop 'A'), moved away from the 'climax' stage during hypoxia, but returned gradually back to the climax stage at the end of this survey. Means of the BHQ indices at the 3 last samplings were between 10.7 and 12.0. The change in faunal structure at Stn 95 followed a similar but wider loop ('B') and had also returned to the 'climax' stage by the last sampling date. The wider loop for Stn 95 compared to Stn 85 demonstrates that the faunal structure during the succession had a greater dissimilarity with the 'climax' community than that at Stn 85. At the last sampling, the mean BHQ index at Stn 95 had increased to $>10$. The benthic fauna at Stns 105 and 118 was already reduced due to hypoxic conditions when sampling began in June 1997, and later that year the fauna was first eliminated at Stn 105 and subsequently at Stn 118. The recovery phases, indicated by Loop 'C', were similar for the benthos at these 2 stations, and the faunal structure changed dramatically during the early part of recovery. At the end of this study, the community structure at these 2 stations approached but did not reach the 'climax' stage, with mean BHQ indices of 9.7 and 8.0, respectively. This suggests that the benthic faunal composition in the Gullmarsfjord at depths from $75 \mathrm{~m}$ down to the deepest basin at $118 \mathrm{~m}$ was fairly similar. This is probably also true for $60 \mathrm{~m}$, as the fauna at that station was similar to that of Stn 75 over a 10 mo period in 1997 and 1998 (Nilsson \& Rosenberg 2000). The distance between the most widely separated stations is about $11 \mathrm{~km}$ and the bottom area below $60 \mathrm{~m}$ depth is close to $14 \mathrm{~km}^{2}$ (Svansson 1984).

From the multivariate analysis we conclude that the benthic fauna succession followed the Pearson-Rosenberg successional model. During the phase of decreasing oxygen concentrations, the benthic communities affected by hypoxia changed from SS III to lower successional stages. The communities at Stns 85 and 95

returned to SS III, and those at the
Fig. 6. Multi-dimensional scaling (MDS) showing benthic faunal succession as means of all stations (numbered according to depth) for all sampling dates between April 1997 and April 2000 combined $(\mathrm{n}=15)$. The octagonal is the 'climax' (Successiona Stage III) or reference (Stn 75) benthic community. The succession during hypoxia and the recovery phase are shown as solid lines. The successional loops in the MDS plot for the different stations are marked A (Stn 95), B (Stn 105) and C (Stn 118) Data for the period April 1997 to April 1998 are from Nilsson \& Rosenberg (2000) 
deeper stations were close to this stage and would probably have reached it later. Thus, SS III is clearly identified by the model, as are SS 0 and SS I, the latter with the typical initial coloniser Capitella capitata. The intermediate community, SS II, had however a different faunal composition between Stns 85 and 95 and Stns 105/118 combined. Thus, the recovery path was not the same as the degradation path, i.e. the benthic system did not show a hysteretic recovery pattern (Westman 1978). However, the communities showed a great resiliency and elasticity. Recovery of benthic fauna following cessation of a fish farm and improved oxygen conditions in Greece generally followed the Pearson-Rosenberg model, but the early stages of succession were affected by the heavy organic enrichment of the sediment (Karakassis et al. 1999). Resiliency of benthic communities following the cessation of hypoxia is dependent on the constituent species, which have different life-cycles, reproduction periods and patterns of larval dispersal (Boesch \& Rosenberg 1981, Llansó 1992). Elasticity means rapid recovery, which is promoted by the presence of undisturbed communities in the vicinity. Such communities can provide colonising larvae. Immigration of adults may also be important for some species, e.g. Amphiura filiformis (Rosenberg et al. 1997). The present study does not, however, support the classification by Molander $(1928,1963)$, whereby several community types exist in the deeper parts of the Gullmarsfjord; rather, the faunal composition recorded suggests only one community-type is present when oxygen concentrations are high enough to meet the fauna's requirements.

\section{LITERATURE CITED}

Baden SP, Loo LO, Pihl L, Rosenberg R (1990) Effects of eutrophication on benthic communities including fishSwedish west coast. Ambio 19:113-122

Bagge P (1969) Effects of pollution on estuarine ecosystems. I. Effects of effluents from wood-processing industries on the hydrography, bottom and fauna of Saltkällefjord (W Sweden). Merenutkimuslaitoksen Julk 228:3-118

Boesch DF, Rosenberg R (1981) Response to stress in marine benthic communities. In: Barett GW, Rosenberg R (eds) Stress effects on natural ecosystems. J Wiley \& Sons, Chichester, p 179-200

Clark KR, Warwick RM (1994) Change in marine communities: an approach to statistical analysis and interpretation. National Environment Research Council, Plymouth

Diaz RJ, Rosenberg R (1995) Marine benthic hypoxia: a review of its ecological effects and behavioural responses of marine macrofauna. Oceanogr Mar Biol Annu Rev 33: 245-303

Gray JS (1992) Eutrophication in the sea. In: Colombo G, Ferrari I, Ceccherelli VU, Rossi R (eds) Marine eutrophication and population dynamics. Olsen \& Olsen, Fredensborg, p 3-13

Gustafsson M, Nordberg K (2001) Living (stained) benthic foraminiferal response to primary production and hydrography in the deepest part of the Gullmar Fjord, Swedish west coast, with comparison to Höglund's 1927 material. J Foraminifer Res 31:2-11

Josefson AB, Widbom B (1988) Differential response of benthic macrofauna and meiofauna to hypoxia in the Gullmar Fjord basin. Mar Biol 100:31-40

Karakassis I, Hatziyanni E, Tsapakis M, Plaiti W (1999) Benthic recovery following cessation of fish farming: a series of successes and catastrophes. Mar Ecol Prog Ser 184: $205-218$

Lardicci C, Como S, Corti S, Rossi F (2001) Recovery of the macrozoobenthic community after severe dystrophic crises in a Mediterranean coastal lagoon (Orbetello, Italy). Mar Pollut Bull 42:202-214

Leppäkoski E (1975) Assessment of degree of pollution on the basis of macrozoobenthos in marine and brackishwater environments. Acta Acad Abo Ser B Math Phys 35:1-90

Llansó RJ (1992) Effects of hypoxia on estuarine benthos: the lower Rappahannock River (Chesapeake Bay), a case study. Estuar Coast Shelf Sci 35:491-515

Mattson S, Cedhagen T (1989) Aspects of the behaviour and ecology of Dyopedos monacanthus (Metzger) and D. porrectus Bate, with comparative notes on Dulichia tuberculata Boeck (Crustacea: Ampipoda: Podoceridae). J Exp Mar Biol Ecol 127:253-272

Molander A (1928) Animal communities on soft bottom areas in the Gullmar Fjord. Kristinebergs Zoological Station, Almaqvist \& Wiksells Boktryckeri, Stockholm

Molander A (1963) The fauna in the fjords of Bohuslän. Ark Zool 15:1-64

Nilsson HC, Rosenberg R (1997) Benthic habitat quality assessment of an oxygen stressed fjord by surface and sediment profile images. J Mar Syst 11:249-264

Nilsson HC, Rosenberg R (2000) Succession in marine benthic habitats and fauna in response to oxygen deficiency: analysed by sediment profile imaging and by grab samples. Mar Ecol Prog Ser 197:139-149

O'Connor BDS, Costolloe J, Keegan BF, Rhoads DC (1989) The use of REMOTS technology in monitoring coastal enrichment resulting from mariculture. Mar Pollut Bull 20:384-390

Pearson TH, Rosenberg R (1976) A comparitive study of the effects on the marine environment of wastes from cellulose industries in Scotland and Sweden. Ambio 5:77-79

Pearson TH, Rosenberg R (1978) Macrobenthic succession in relation to organic enrichment and pollution of the marine environment. Oceanogr Mar Biol Annu Rev 16: 229-311

Petersen CGJ (1913) Valuation of the sea. 2. The animal communities of the sea bottom and their importance for marine zoogeography. Rep Dan Biol Stn 16:229-311

Peterson CH, Kennicutt MC II, Green RH, Montagna P, Harper DE, Powell EN, Roscigno PF (1996) Ecological consequences of environmental perturbations associated with offshore hydrocarbon production: a perspective on longterm exposures in the Gulf of Mexico. Can J Fish Aquat Sci 53:2637-2654

Rhoads DC, Cande S (1971) Sediment profile camera for in situ study of organism-sediment relations. Limnol Oceanogr 16:110-114

Rhoads DC, Germano JD (1982) Characterization of organism-sediment relations using sediment profile imaging: an efficient method of remote ecological monitoring of the seafloor. Mar Ecol Prog Ser 8:115-128

Rhoads DC, Germano JD (1986) Interpreting long-term 
changes in benthic community structure: a new protocol. Hydrobiologia 142: 291-308

Rosenberg R (1972) Benthic faunal recovery in a Swedish fjord following the closure of a sulphite pulp mill. Oikos 23:92-108

Rosenberg R (1976) Benthic faunal dynamics during succession following pollution abatement in a Swedish estuary. Oikos 27:414-427

Rosenberg R, Diaz RJ (1993) Sulfur bacteria (Beggiatoa spp.) mats indicate hypoxic conditions in the inner Stockholm Archipelago. Ambio 22:32-36

Rosenberg R, Nilsson HC, Hollertz K, Hellman B (1997) Density-dependent migration in an Amphiura filiformis (Amphiuridae, Echinodermata) infaunal population. Mar Ecol Prog Ser 159:121-131

Rosenberg R, Nilsson HC, Diaz RJ (2001) Response of benthic fauna and changing sediment redox profiles over a hypoxic gradient. Estuar Coast Shelf Sci 53:343-350

Rumohr H, Karakassis I (1999) Comparison of multivariate patterns: different taxonomic levels in macrofaunal analysis versus sediment profile imagery (SPI). Mar Ecol Prog Ser 190:125-132

Editorial responsibility: Otto Kinne (Editor),

Oldendorf/Luhe, Germany
Svansson A (1984) Hydrography of the Gullmar Fjord. Fisheries Board of Sweden. Inst Hydrogr Res Ser 23:1-14

Swartz R, Schults D, Ditsworth G, DeBen W, Cole F (1985) Sediment toxicity, contamination, and macrobenthic communities near a large sewage outfall. In: Boyle TP (ed) Validation and predictability of laboratory methods for assessing the fate and effects of contaminants in aquatic systems, Vol 865. American Society for Testing and Materials, Philadelphia, p 152-175

Thorson G (1957) Bottom communities (sublittoral or shallow shelf). Geol Soc Am Mem 67:461-534

Tsutsumi H (1987) Population dynamics of Capitella capitata (Polychaeta; Capitellidae) in an organically polluted cove. Mar Ecol Prog Ser 36:139-149

Warwick RM, Clarke KR (1993) Comparing the severity of disturbance: a meta-analysis of marine macrobenthic community data. Mar Ecol Prog Ser 92:221-231

Westman WE (1978) Measuring the inertia and resilience of ecosystems. BioScience 28:705-710

Weston DP (1990) Quantitative examination of macrobenthic community changes along an organic enrichment gradient. Mar Ecol Prog Ser 61:233-244

Submitted: August 27, 2001; Accepted: November 15, 2001 Proofs received from author(s): May 6, 2002 